\title{
Effects of thyroid state alterations in ovo on the plasma levels of thyroid hormones and on the populations of fibers in the plantaris muscle of male and female chickens
}

\author{
J Dainat 1, L Saleh 2, C Bressot 2, \\ L Marger 2, F Bacou 2, P Vigneron 2* \\ 1 INRA and USTL, Laboratoire de Neurobiologie, 34060 Montpellier Cedex; \\ 2 INRA, Laboratoire de Différenciation Cellulaire et Croissance, 34060 Montpellier Cedex, France
}

(Received 2 July 1990; accepted 19 September 1991)

\begin{abstract}
Summary - Propylthiouracil (PTU), thyroxine (T4) or thyreoliberin (TRH) were injected in ovo to modify the thyroid state of chicken embryos. Significant sexual differences were observed in the effects of these treatments on the plasma concentrations of thyroid hormones and on plantaris muscle characteristics (DNA, RNA, populations of muscle fibers) in 3- and 35-day old male and female chickens. The T4 plasma concentration is lower in control males; it is decreased in PTU treated females and in the T4 treated females at 35 days. The T3 plasma concentration is lowered at 3 days in all treated chickens and also at $\mathbf{3 5}$ days in the TRH treated animals. The slow (STnO) and the fast (FTOG) fibers of the plantaris are always more numerous in males. In controls, the number of FTOG fibers remains steady between 3 and 35 days; at the same time, the number of STnO fibers rises in males only. Both PTU and T4 treatments increase the number of the FTOG and the STnO fibers respectively before and after the 3rd day. TRH treatment increases the number of STnO fibers at 3 and 35 days in males, but reduces it at 3 days in females. Thus changes in the number of FTOG fibers can be induced during in ovo myogenesis, whereas the number of STnO fibers may increase after hatching.
\end{abstract}

chicken / thyroid hormones / muscle fibers / skeletal muscle

Résumé - Effets de modifications in ovo de l'état thyroïdien sur les teneurs plasmatiques d'hormones thyroiddlennes et sur les populations de flbres du muscle plantaris chez des poulets mâles et femelles. Du propylthiouracile (PTU), de la thyroxine (T4) ou de la thyréoliberine (TRH), ont été administrés in ovo afin de modifier l'état thyroïdien chez l'embryon de poulet. Ces traitements montrent de fortes differences sexuelles dans leurs effets sur le niveau plasmatique des hormones thyrö̈diennes et sur plusieurs caractéristiques (ADN, ARN, populations de fibres) du muscle plantaris chez des poulets de 3 et 35 jours des deux sexes. La concentration plasmatique de T4 est inférieure chez les témoins mâles; elle est abaissée chez les femelles traitées par le PTU et à 35 jours, chez les femelles traitées T4. La concentration plasmatique de T3 est abaissée à 3 jours chez tous les poussins traités et à 35 jours chez les poussins traités TRH. Les fibres musculaires

\footnotetext{
* Correspondence and reprints
} 
lentes (STnO) et les fibres rapides (FTOG) du plantaris sont toujours plus nombreuses chez les mâles. Chez les témoins entre 3 et 35 jours, le nombre de fibres FTOG ne varie pas alors que le nombre de STnO s'accroît, mais seulement chez les mâles. Les traitements PTU et T4 augmentent le nombre oe fibres FTOG et STnO respectivement avant et après le 3e jour. TRH in ovo accroit le nombre de fibres STnO à 3 et à 35 jours chez les mâles, mais le diminue à 3 jours chez les femelles. Ainsi, des modifications du nombre de fibres FTOG peuvent être induites lors de la myogenèse, in ovo, alors que le nombre de fibres STnO peut augmenter après l'éclosion.

poulet / hormones thyroïdiennes / fibres musculaires / muscle squelettique

\section{INTRODUCTION}

The skeletal muscle is made up of multinucleated fibers belonging to 3 main categories. In the terminology of Peter et al (1972), they are classified according to their speed of contraction and metabolism: 1), fast-twitch glycolytic fibers (FTG); 2), fast-twitch oxido-glycolytic fibers (FTOG) and slow-twitch oxidative fibers (STO). In birds, STO fibers are present but the slow fibers are mostly slow tonic multiinnervated oxidative fibers, here noted as STnO fibers.

In birds as in mammals, thyroid hormones (TH) contribute to the regulation of the ponderal growth and to the regulation of multiple biological processes. TH play a pivotal role in the differentiation and the maturation of many tissues; in muscle, $\mathrm{TH}$ can change the total number of fibers (TNF) and regulate the relative abundance of muscle fibers of various types.

In adult rats, surgical hypothyroidectomy decreases the body weight and lowers the percentage of the fast-twitch fibers in the 4 muscles studied (soleus, plantaris, adductor longus, diaphragma) whereas hyperthyroidism induced by T3 injection decreases body weight but increases the percentage of fast-twitch fibers in the same muscles (lanuzzo et al, 1980).

In the fowl, the in ovo administration of methylmercaptoimidazole, an antithyroid drug, increases the number of FTOG fibers in the plantaris and flexor digitorum muscles of adult male chickens (Bacou et al, 1980).

Thus, an acute modification of the thyroid state during endocrine system ontogeny eventually modified tissue differentiation and probably modified growth and development.

These results led us to study in 3- and 35-day old male and female chickens the effects of experimental alterations in thyroid state during embryogenesis. We focused on the plasma levels of thyroid hormones, the populations of muscle fibers and the DNA and RNA content of the plantaris muscle, chosen on the basis of its mixed fiber composition (FTOG and STnO).

\section{MATERIALS AND METHODS}

$\mathrm{NaOH}$, perchloric acid (PCA) were supplied by Merck; bovine albumin, RNA, DNA, propylthiouracil (PTU), thyroxine (T4), triiodothyronine (T3) were supplied by Sigma, thyreoliberine (TRH) by Bachem, T4 and T3 RIA kits by BioMerieux.

We bred our line of New Hampshire Cll chickens. Eggs were incubated at $37.8 \pm 0.2^{\circ} \mathrm{C}$ in a 'La Nationale' forced-draft incubator. The age of the embryos was the time the eggs remained in the incubator. On day 18 of incubation, eggs were placed in the hatchery. After hatching, the chickens were kept in an animal house maintained at $22^{\circ} \mathrm{C}$ with infrared heating complement and 12L-12D photoperiod. They were fed ad libitum on a corn, wheat and soybean meal based diet $(2900 \mathrm{Kcal} \mathrm{ME} / \mathrm{kg} ; 19 \%$ protein). 
Eggs were injected once in the air space on the chorioallantoic membrane with $100 \mu \mathrm{l}$ of aqueous solutions containing: for PTU chickens: $1 \mathrm{mg}$ of PTU, at day 7 of incubation; for T4 chickens: $100 \mathrm{ng}$ of $\mathrm{T} 4$, at day 10 of incubation; for TRH chickens: $1 \mu \mathrm{g}$ of $\mathrm{TRH}$, at day $i 0$ of incubation.

For injections, the chronology and the doses were chosen according to preliminary experiments where thyroid physiology, hatching levels and effects on the plantaris muscle were considered. We tested $0.5 \mathrm{mg}$ and $1 \mathrm{mg}$ of PTU at day 3 or 7 of incubation, in order to prevent or delay the onset of T4 and T3 secretions. We also performed 1, 2 or $3100 \mathrm{ng} \mathrm{T4}$ injections between day 6 and 16 . In all cases, repeated injections, at 2-day intervals, decreased hatching levels. Higher doses were also unfavourable. The optimum date of injection appeared to be the 10th day. Single injections of $10 \mathrm{ng}, 100 \mathrm{ng}, 1 \mu \mathrm{g}$, $10 \mu \mathrm{g}$ and $20 \mu \mathrm{g}$ of TRH were tested at the same age retained for $T 4 ; 1 \mu \mathrm{g}$ was chosen.

Control animals received an injection of 100 $\mu l$ of sterile water, which as a preceding experiment showed displayed no effect. Each treatment was performed on 4 distinct groups of eggs, including controls; at least 8 animals were used to analyse the muscle characteristics for one sex at one age and for one treatment.

In 3- and 35-day old chickens under ether anaesthesia, a few minutes before sacrifice, heart blood was sampled on heparin and centrifuged for $10 \mathrm{~min}$ at $8000 \mathrm{~g}$ in an Eppendorf centrifuge. The plasma was stored at $-20^{\circ} \mathrm{C}$ until the time of T4 and T3 assays.

Both plantaris muscles were cut off and weighed. One muscle was frozen in dry ice and stored at $-20^{\circ} \mathrm{C}$ until DNA and RNA analysis. The other was quickly frozen in dry ice-cooled isopentane and stored at $-70{ }^{\circ} \mathrm{C}$ for histoenzymatic studies.

\section{Muscle fiber typing and measurements}

Transverse $12-\mu \mathrm{m}$ thick serial sections were cut with a cryostat microtome through the upper part of the muscles, just underneath the proximal insertion, in order to count the whole number of fibers. The sections were air-dried at $4^{\circ} \mathrm{C}$ and reacted for myofibrillar ATPase after acid preincubation according to the technique of
Guth and Samaha (1969), which had been slightly modified by Ashmore et al (1978). All quantitative histology was performed using a Visopan Reichert projection microscope.

\section{DNA and RNA assays}

The technique of Dainat and Rebiere (1978) was used with slight modifications. All operations were carried out at $0^{\circ} \mathrm{C}$. One plantaris muscle was homogenized using an Ultraturrax in $2.5 \mathrm{ml}$ of $0.4 \mathrm{~N} \mathrm{PCA}$. The final homogenate was centrifuged at $2500 \mathrm{~g}$ for $20 \mathrm{~min}$ and the supernatant discarded. The pellet was washed once in $1 \mathrm{ml}$ PCA $0.2 \mathrm{~N}$ and the supernatant discarded. The new pellet was dissolved in $2.5 \mathrm{ml}$ $0.3 \mathrm{~N} \mathrm{NaOH}$ and incubated at $37^{\circ} \mathrm{C}$ for $1 \mathrm{~h}$. $0.35 \mathrm{ml} 3 \mathrm{~N}$ ice cold PCA were added and the samples were maintained on ice for $10 \mathrm{~min}$ before centrifugation ( $2500 \mathrm{~g}$ for $20 \mathrm{~min}$ ). The supernatant was collected and the pellet washed once in $2 \mathrm{ml}$ of $0.4 \mathrm{~N} \mathrm{PCA}$. Both supernatants were pooled for RNA determination. The pellet was further dissolved in $2.5 \mathrm{ml} 0.3 \mathrm{~N} \mathrm{NaOH}$. The solution was made acidic with $0.4 \mathrm{ml} 3 \mathrm{~N}$ icecold PCA and further with $0.7 \mathrm{ml} 1 \mathrm{~N} \mathrm{PCA}$; the samples were then heated to $70{ }^{\circ} \mathrm{C}$ for $15 \mathrm{~min}$ and quickly refrigerated in ice for $10 \mathrm{~min}$. The supernatant was kept and the pellet was collected once in $1 \mathrm{ml}$ PCA $0.2 \mathrm{~N}$. Both supernatants were pooled for DNA determination.

RNA and DNA were estimated by spectrophotometric determination, at $260 \mathrm{~nm}$ for RNA using yeast RNA as standard, and at $266 \mathrm{~nm}$ for DNA using calf thymus DNA as standard.

\section{T4 and T3 assays}

Plasma T4 or T3 assays were carried out simultaneously on control and experimental samples for each stage. Total plasma T4 or T3 concentrations were measured in duplicate by the radioimmunoassay method with T4 or T3 specific antibodies (anti-T3 or anti-T4 rabbit serum) coated on the bottom of test tubes (BioMerieux 125| T4 and 125| T3 coat RIA). The reaction was performed in Tris- $\mathrm{NaCl}$ buffer $\mathrm{pH} 8.6$ with 8anilino-1-naphthalene-sulfonic acid and natrium salicylate to eliminate interference due to serum binding proteins (TBG, TBPA, albumin) and to 
allow a direct assay of T4 and T3. Standards were developed using chicken plasma depleted of TH on charcoal dextran. The assays were performed by incubation of $100 \mu \mathrm{l}$ of plasma at $37^{\circ} \mathrm{C}$ for $1 \mathrm{~h}$ with $400 \mu \mathrm{l}$ of $125 \mathrm{~T}$ T3 or 125 T4 in test tubes coated with anti-T3 or anti-T4 antibodies. After incubation, the solutions were discarded and the test tubes rinsed in $2 \mathrm{ml}$ of water. The radioactivity was measured in a gamma counter. The values were calculated using a logit-log standard curve derived from 5 duplicates of various hormone concentrations. The minimum amount of T3 and T4 significantly differing from the 0 concentration with a probability of $95 \%$ was $0.2 \mathrm{nM}$ and $0.5 \mathrm{nM}$ respectively. Percentage of cross-reactivity at $\mathrm{B} / \mathrm{BO}=0.5$ was 100 for triiodothyronine and 0.15 for L-thyroxine with the T3-kit, and 100 for thyroxine and 4.5 for L-triiodothyronine with the T4 kit.

\section{Statistical analyses}

Statistical analyses were performed by 1-way or 2-way ANOVA analysis of variance. The differences in mean values were further analysed using 1-way ANOVA between controls and each treatment of the same sex and the same age, and between ages for each treatment.

\section{RESULTS}

In the PTU treated chickens, hatching occurred 3 days later than in controls; there was a $40 \%$ range of hatching ability. $\mathrm{TRH}$ treated chickens hatched 0.5 day in advance. The hatching ability and the survival of T4 and TRH treated animals were similar to that of controls.

The plasma levels of $\mathrm{T} 4$ and $\mathrm{T} 3$ varied respectively from 2.73 to $6.61 \mathrm{ng} / \mathrm{ml}$ and from 0.59 to $2.58 \mathrm{ng} / \mathrm{ml}$ (fig 1 ). In controls and in TRH-treated chickens T4 levels were lower in males. PTU and T4 treatments tended to reverse these sexual differences.

The PTU treatment resulted in a significant lowering of T4 and T3 plasma concentrations in the 3-day old chickens. The T4 treatment lowered the levels of T4 at
35 days and T3 at 3 days. The TRH treatment lowered T3 at 3 and 35 days.

Body weight and muscle plantaris weight (fig 2) were lowered at 3 days in PTU and TRH treated chickens and enhanced at 35 days. The plantaris muscle weight increase seemed related to higher quantities of muscle RNA, especially in $\mathrm{TRH}$ treated animals where the values were about twice the control values (fig 3). The RNA/DNA ratio was higher in all treated 35-day old chickens; it was only slightly elevated on the 3rd day by the T4 injection.

The DNA plantaris muscle content increased $\approx 10$-fold between days 3 and 35 . The T4 treatment increased the DNA plantaris content at 3 days and decreased it at 35 days (fig 4). TRH treatment increased the DNA plantaris content at 35 days.

In controls and in treated male chickens, the number of slow and fast muscle fibers (fig 5), and consequently the total number of fibers (TNF) (fig 4) were higher than in females. In controls, the TNF remained steady in females, but increased from 3 to 35 days in males due to a preferential increase of the number of slow fibers. All treatments enhanced the TNF at each studied age, except for TRH treated females; the increases in TNF were related to a higher number of fast fibers from the 3rd day on, and to a gradual increase of slow fibers between 3 and 35 days.

The cross-sectional areas of STnO fibers did not differ between males and females and between controls and treated chickens; the mean was $234 \pm 56 \mu \mathrm{m}^{2}$ at 3 days and $1162 \pm 279 \mu \mathrm{m}^{2}$ at 35 days. The cross-sectional areas of FTOG fibers were higher in females at 3 days, $272 \pm 80 \mu \mathrm{m}^{2}$ versus $228 \pm 54 \mu \mathrm{m}^{2}$. At 35 days, they were slightly higher in PTU treated females ( $1683 \pm 192 \mu \mathrm{m}^{2}$ ) as compared to the mean of other male and female chickens (1 $429 \pm 343 \mu \mathrm{m}^{2}$ ). 


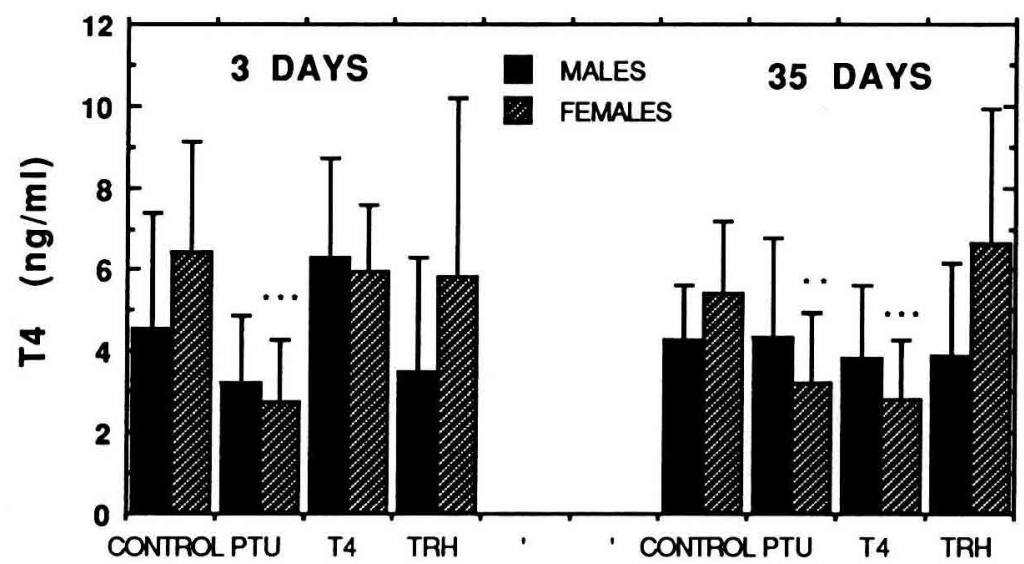

Significance :

$\begin{array}{lcccccccc}\text { Treatments } & - & 0.000 & 0.121 & 0.464 & - & 0.015 & 0.002 & 0.813 \\ \text { Sexes } & 0.042 & 0.092 & 0.089 & 0.014 & 0.029 & 0.428 & 0.124 & 0.004 \\ \text { Interaction } & - & 0.069 & 0.085 & 0.783 & - & 0.020 & 0.033 & 0.120\end{array}$

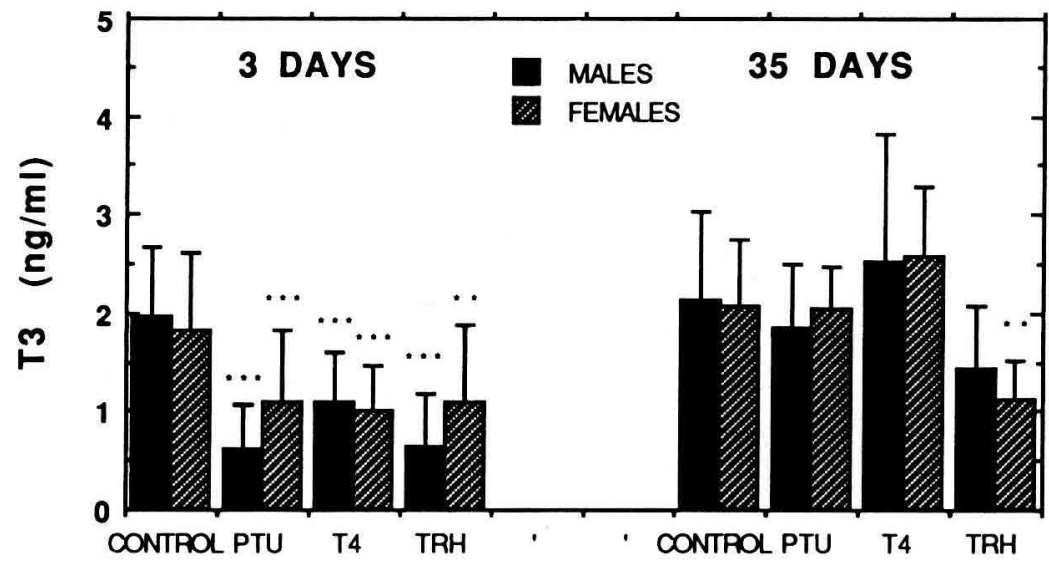

Significance :

$\begin{array}{lcccccccc}\text { Treatments } & - & 0.000 & 0.000 & 0.000 & - & 0.453 & 0.123 & 0.001 \\ \text { Sexes } & 0.783 & 0.120 & 0.973 & 0.113 & 0.887 & 0.858 & 0.787 & 0.530 \\ \text { Interaction } & - & 0.094 & 0.626 & 0.383 & - & 0.623 & 0.982 & 0.561\end{array}$

Fig 1. Effects of the administration of PTU, T4 and TRH on the plasma levels of T4 and T3 in male and female chickens at 3 and 35 days. Values are means \pm SD. Significance was calculated by variance analysis. 1-way ANOVA: at each age between males and females in controls; between treated and controls for a same sex $\left({ }^{*}\right) ;\left({ }^{*} P<0.05 ;{ }^{* *} P<0.01 ;{ }^{* * *} P<0.001\right)$. 2-way ANOVA: between controls and treated animals. 

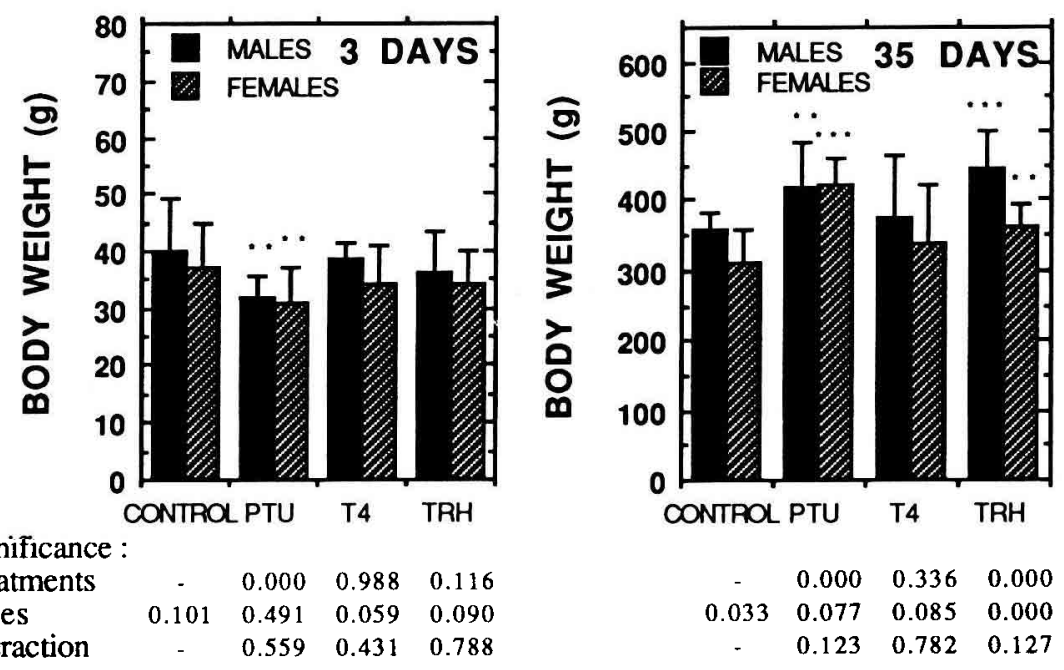

Significance :

$\begin{array}{lcccc}\text { Treatments } & - & 0.000 & 0.988 & 0.116 \\ \text { Sexes } & 0.101 & 0.491 & 0.059 & 0.090 \\ \text { Interaction } & - & 0.559 & 0.431 & 0.788\end{array}$
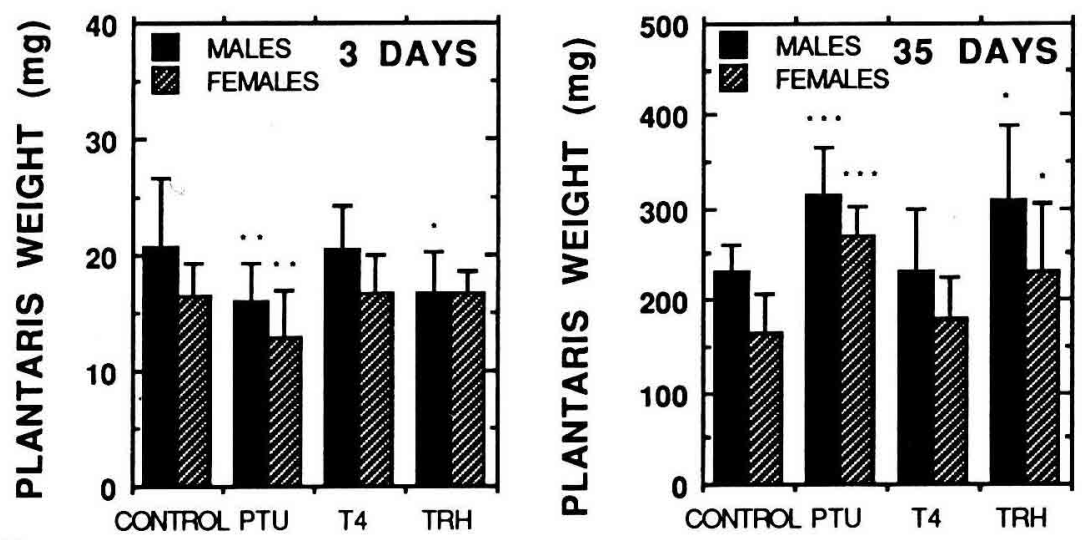

Significance :

$\begin{array}{lcccc}\text { Treatments } & - & 0.006 & 0.915 & 0.042 \\ \text { Sexes } & 0.023 & 0.000 & 0.002 & 0.083 \\ \text { Interaction } & - & 0.684 & 0.985 & 0.069\end{array}$

$$
\begin{array}{cccc}
- & 0.000 & 0.457 & 0.001 \\
0.002 & 0.000 & 0.001 & 0.001 \\
- & 0.509 & 0.407 & 0,749
\end{array}
$$

Fig 2. Body weight and plantaris muscle weight of 3- and 35-day old male and female chickens treated in ovo with PTU, T4 or TRH. Values are means \pm SD. Significance was calculated by variance analysis. 1-way ANOVA: at each age between males and females in controls; between treated and controls for a same sex $\left({ }^{*}\right) ;\left({ }^{*} P<0.05 ;{ }^{* *} P<0.01 ;{ }^{* * *} P<0.001\right)$. 2-way ANOVA: between controls and treated animals. 

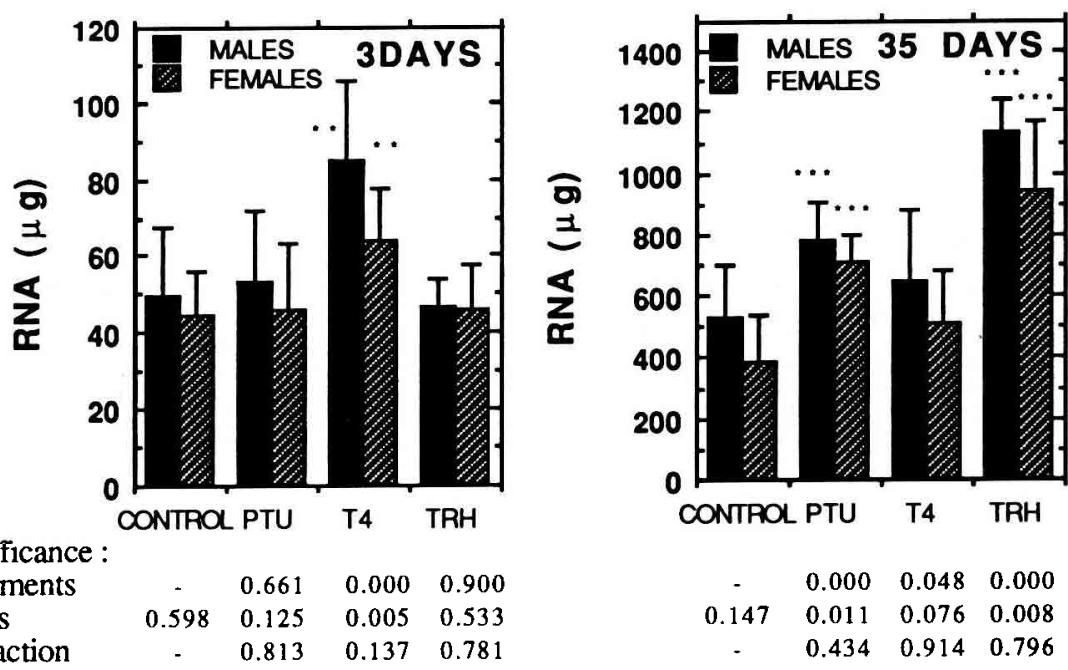

Significance :

$\begin{array}{lcccc}\text { Treatments } & & 0.661 & 0.000 & 0.900 \\ \text { Sexes } & 0.598 & 0.125 & 0.005 & 0.533 \\ \text { Interaction } & - & 0.813 & 0.137 & 0.781\end{array}$

-

$0.434 \quad 0.914 \quad 0.796$

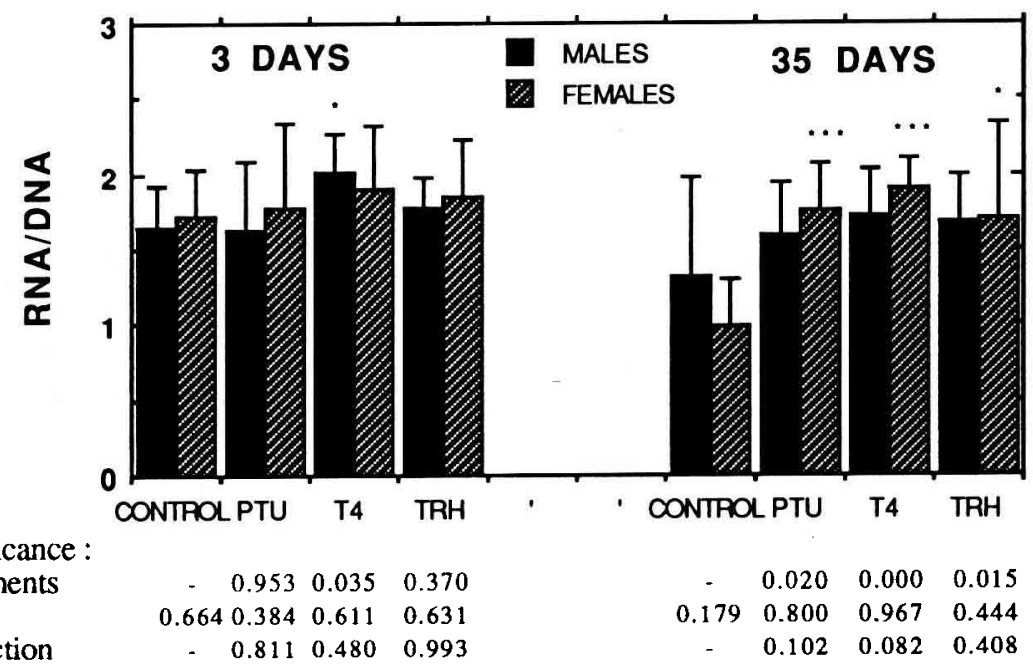

Fig 3. RNA and RNA/DNA contents of the plantaris muscle in 3- and 35- day old male and female chickens treated in ovo with PTU, T4 or TRH. Values are means \pm SD. Significance was calculated by variance analysis. 1-way ANOVA: at each age between males and females in controls; between treated and controls for a same sex $\left({ }^{*}\right) ;\left({ }^{*} P<0.05 ;{ }^{* *} P<0.01\right.$; $\left.{ }^{* * *} P<0.001\right)$. 2-way ANOVA: between controls and treated animals. 

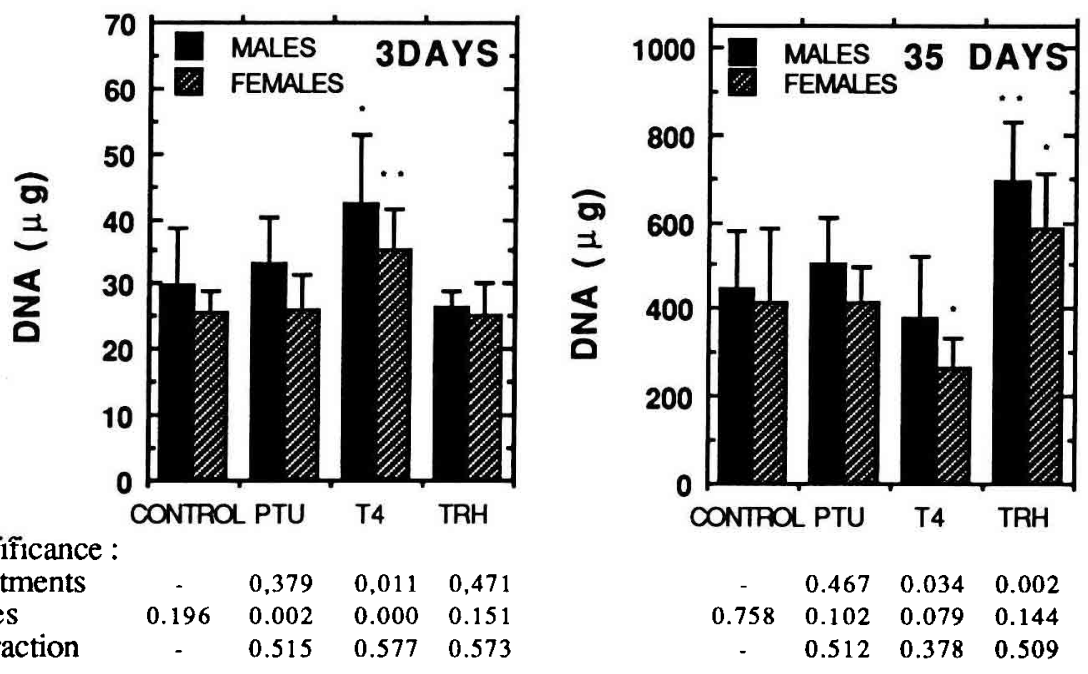

Significance :

$\begin{array}{lcccc}\text { Treatments } & - & 0,379 & 0,011 & 0,471 \\ \text { Sexes } & 0.196 & 0.002 & 0.000 & 0.151 \\ \text { Interaction } & - & 0.515 & 0.577 & 0.573\end{array}$

$\begin{array}{cccc}- & 0.467 & 0.034 & 0.002 \\ 0.758 & 0.102 & 0.079 & 0.144 \\ - & 0.512 & 0.378 & 0.509\end{array}$

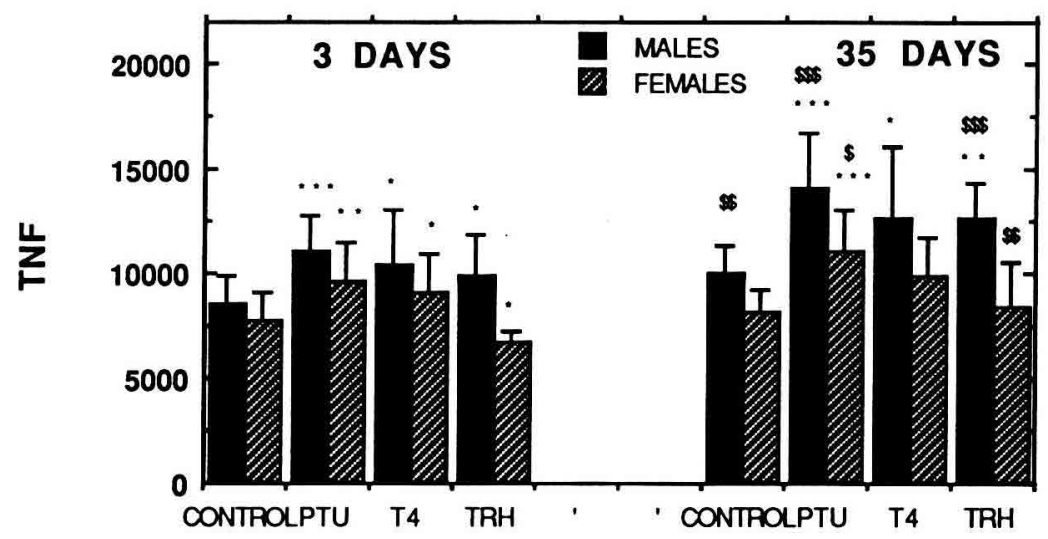

Significance :

Treatments

Sexes

Interaction

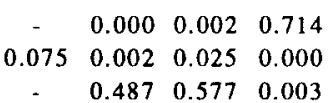

$\begin{array}{cccc}- & 0.000 & 0.007 & 0.018 \\ 0.005 & 0.000 & 0.001 & 0.000 \\ - & 0.484 & 0.548 & 0.039\end{array}$

Fig 4. DNA content and total number of fibers (TNF) in the plantaris muscle of 3- and 35-day old male and female chickens treated in ovo with PTU, T4 or TRH. Values are means \pm SD. Significance was calculated by variance analysis. 1-way ANOVA: at each age between males and females in controls; between treated and controls for a same sex (*); $\left(^{*} P<0.05 ;{ }^{* \star} P<0.01\right.$; $\left.{ }^{* * *} P<0.001\right)$. 2-way ANOVA: between controls and treated animals; between 3 and 35 days for a same sex and treatment $(\$) ;\left({ }^{*}, \$ P<0.05 ;{ }^{* *}, \$ P<0.01 ; * * *\right.$ \$ $\left.\$ P<0.001\right)$. 


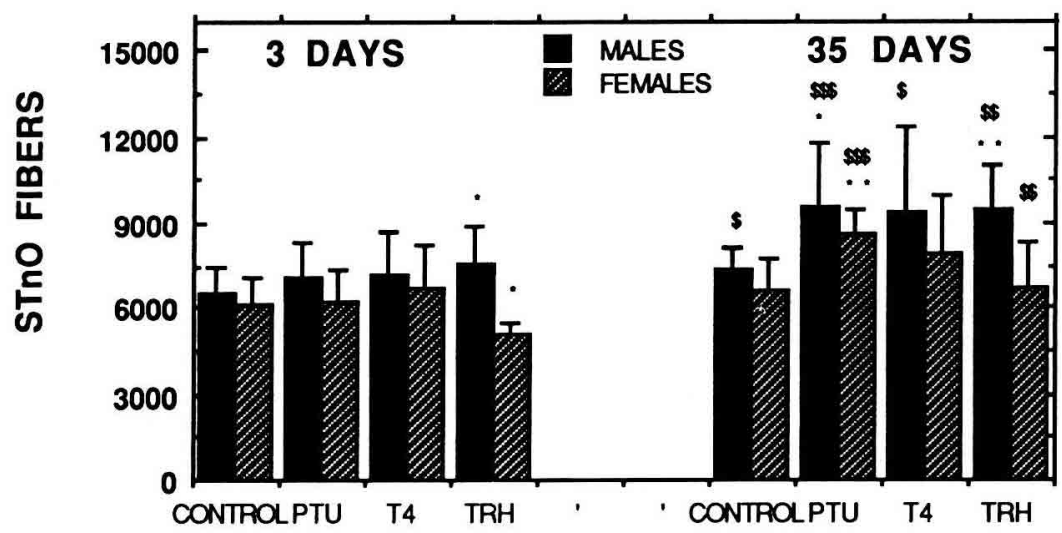

Significance :

Treatments

Sexes

Interaction

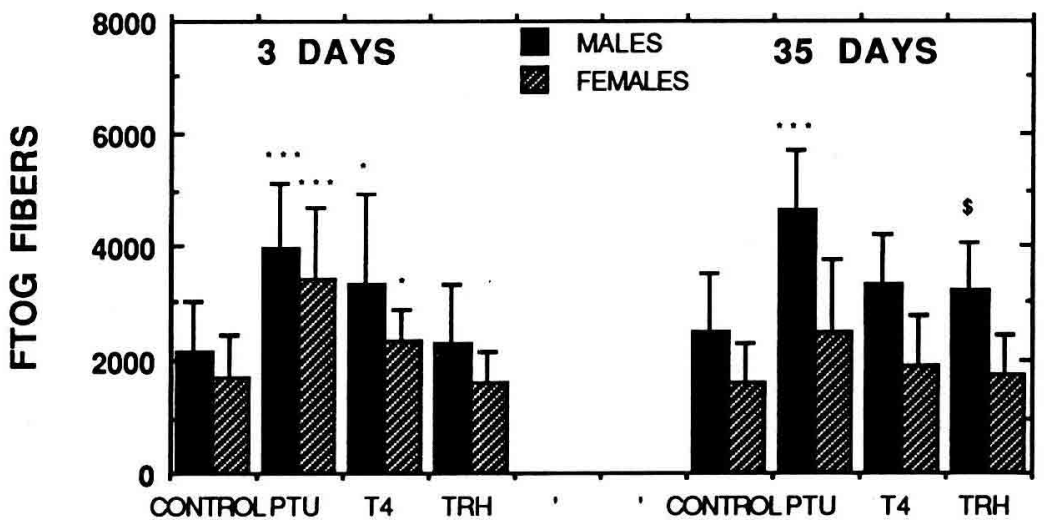

Significance :

Treatments

Sexes

Interaction

$\begin{array}{cccc} & 0.000 & 0.003 & 0.810 \\ 0.102 & 0.009 & 0.018 & 0.010 \\ - & 0.861 & 0.369 & 0.162\end{array}$

Fig 5. Numbers of fast (FTOG) and slow (STnO) fibers in the plantaris muscle of 3- and 35-day old male and female chickens treated in ovo with PTU, T4 or TRH. Values are means \pm SD. Significance was calculated by variance analysis. 1-way ANOVA: at each age between males and females in controls; between treated and controls for a same sex $\left({ }^{*}\right)$; between 3 to 35 days for a same sex and treatment $(\$) ;\left(^{*}, \$ P<0.05 ;{ }^{* *}, \$ \$ P<0.01 ;{ }^{* * *}, \$ \$ \$ P<0.001\right)$. 2-way ANOVA: between controls and treated animals. 


\section{DISCUSSION}

The low hatching values of in ovo PTU treated embryos and their delay in hatching are mainly due to a resorption defect of the yolk sac as reported for other antithyroid drugs (Adams and Bull, 1949; Goussopoulos et al, 1974). The slight speeding up of hatching time in the TRH treated embryos seems related to an acceleration of the maturation processes.

\section{Plasma levels of T4 and T3}

The T4 plasma concentrations measured by RIA in this experiment are lower than in other breeds (Klandorf et al, 1978; Hylka et al, 1986); they correspond to the values obtained with the ELISA technique (data not shown) and competition assay (Bacou et al, 1980). The T3 plasma concentrations equal the values reported for other breeds (Newcomer, 1974; Bobek et al, 1977; Klandorf et al, 1978; Kühn et al, 1982; Hylka et al, 1986).

We found a sexual difference in the T4 plasma concentration which was higher in females, as reported by Bacou et al (1980). Such sexual difference may correspond to higher peripheral tissue deiodinase activities in males, as measured in chicken muscle (Dainat et al, in preparation) or in rat liver and kidney (Harris et al, 1979; Coka, 1979). TRH treatment does not change these sexual differences, whereas PTU and T4 treatments tend to inverse them, perhaps by modifying the maturation of the thyroid and of the gonadal axis and/or the activities of the peripheral cellular deiodinase activities.

We also found a sexual difference in the effects of PTU and T4 treatments on plasma T4 concentrations. In ovo, PTU as MMI (Bacou et al, 1980) induces a persistently low level of T4 which is maintained after hatching in females only until the 35th day. Since T4 plasma concentrations are higher in control females, some kind of interaction between female steroids and T4 secretion may exist, perhaps through progesterone, which peaks in ovo (Kalliekaran and Hall, 1974) at the same time as T4; this could also explain the higher peak of T4 in females (Bacou et al, 1980). As for other tissues, the hypothyroidism induced in ovo by PTU could delay the maturation of the ovary and reduce the progesterone secretion.

As T3 is considered the active hormone, all treatments appear to induce hypothyroidism during the perinatal period. This state evolves to euthyroidism at 35 days in PTU and T4 treated animals but persists in TRH treated females. The lower plasma T3 concentrations could be due to various mechanisms such as a decrease of T3 secretion by the thyroid gland and/or a decrease of tissue T4 5' deiodinase activity.

PTU hypothyroidism is linked to decreased tissue T4 5'deiodinase activities, as observed in rats (Oppenheimer et al, 1972; Leonard and Rosenberg, 1978; Silva and Mattews, 1984) and in other species (Geffner et al, 1975). In ovo, this drug or some metabolite could persist and remain active until hatching when it could be eliminated. T4 and TRH, which are physiologically quickly metabolized into ineffective compounds, likely affect the thyroid state in a different way. We suspect that they may bring about transient hyperthyroidism which could interfere with the maturation of the deiodinase system, lowering the T4 5'deiodinase activity, whereas T4 and TRH respectively stimulate this activity in adult rat liver and kidney (Grussendorf and Hüfner, 1977; Kaplan and Utiger, 1978; Van Doorn et al, 1982; Jennings et al, 1984) and in adult chicken liver (Kühn et al, 1986). TRH is also able to stimulate growth hormone secretion in immature chickens (Decuypere and Scanes, 1983; 
Huybrecht et al, 1985; Scanes et al, 1987; Harvey, 1990); in chickens this hormone increases the $5^{\prime}$ monodeiodinase activity in embryonic and in adult liver (Kühn et al, 1986; Darras et al, 1990). Otherwise T4 and TRH could have induced a reactional hypothyroidism, but this hypothesis is less probable since hatching occurs within a normal space of time or is even slightly accelerated in TRH treated chickens. In this case the recovery at 35 days is delayed, particularly in females where T4 levels are still within the normal range.

Thus, after hatching our treatments induced decreases in the plasma concentrations of thyroid hormones probably in relationship with alterations in the ontogeny of various hormonal systems. At this stage, the maturation of the thyroid gland must also be affected, but other modifications could be involved which we are now investigating: thyroid hormones levels, hormone metabolism and clearance, tissue deiodinase activities.

\section{Fiber populations in the plantaris muscle}

Increases in plantaris total number of muscle fibers (TNF) were ascertained in all treated chickens, with the exception of TRH treated females. These changes correspond to alterations of the in ovo myogenesis since they were measured from the 3rd day after hatching, but they also correspond to modifications in the postnatal evolution of TNF. Moreover, the treatments diversely affected the various populations of muscle fibers.

In PTU treated chickens the TNF is greater, as Bacou et al (1980) reported in MMl treated males. This could be explained by a precocious effect of hypothyroidism on myogenesis and/or development of the motor neurones as the T3 plasma concentration is low at 3 days. This higher TNF is based upon an increase in both slow and fast fiber numbers. However, a striking difference appears in the effects of PTU treatment on fiber populations: the increase in fast fibers occurs only before hatching, whereas the number of slow fibers increases between hatching and 35 days. This increase is higher in treated males than in controls. In control females, there is no change but in the treated females the slow fiber number increases as much as in treated males.

The post-natal increase of STnO fibers in PTU treated chickens may rely on hyperplasy either of myoblasts still present in the muscle at this stage or of satellite cells, extending myogenesis after hatching. A further conversion of fibers from one type to another could occur during development since in adults treated in ovo by MMI, Bacou et al (1980) only observed a significant increase in fast fibers, which could be related to a transformation of slow fibers into fast fibers as an adaptation to functional requirements.

As with PTU but to a lesser degree, T4 injected in ovo increases the TNF and the numbers of slow and fast fibers, but perinatal myogenesis seems accelerated as FTOG, DNA and RNA values are higher at 3 days, but equal or slightly under normal values at 35 days. The increases in slow and fast fiber numbers may be linked to the transitory perinatal hypothyroidism observed.

TRH administration in ovo increases TNF in males at 35 days. As compared to PTU and T4 effects, this is based upon highly different hormonal and tissual evolution and upon strong sex/TRH interferences on myogenesis. At 3 days, STnO fiber numbers of TRH treated chickens are higher in males and lower in females than in controls. In both sexes, the STnO fiber number increases after hatching, reaching 
normal values in females. FTOG fiber numbers equal normal values at 3 days, and rise until 35 days in males. This postnatal evolution of both populations of fibers corresponds to dramatic increases in muscle DNA and RNA contents. As the TNF is increased in males within the same range as in other treatments, the cellular units must be more numerous, of lower size, and could correspond to higher growth potential or to the speeding up of some processes. In TRH treated animals, the T3 plasma concentration remains lower at 35 days. Thus, as in other treatments, some degree of hypothyroidism does not inhibit DNA and RNA synthesis, but could even stimulate them in muscle and possibly in other tissues since at 35 days the fiber number increase corresponds to higher plantaris and body weights.

Other mechanisms could be implicated. For example, a "trophic effect" of TRH on fetal rat spinal motor neurones in cultures has beein described (Schmidt-Achert et al, 1984). In vivo, this could result in a greater survival of motor neurones during embryonic life, and in a related increase in the number of fibers (Ross et al, 1987).

Our treatments interfere with myogenesis. They have quantitative rather than qualitative effects. Thus, PTU in ovo in the chicken and an experimental hypothyroidism in newborn or in adult rats differently affect the populations of muscle fibers. In newborn rats, PTU administration from birth inhibits the normal increase of slow and fast fiber numbers in the soleus muscle (Sugie and Verity, 1985). But this also induces muscle metabolic disturbances (Nemeth et al, 1989) and a marked diminution of body weight and cell multiplication. Since early postnatal protein restriction in rats and malnutrition in mice inhibit the increase of fast and slow fiber numbers (Ihemelandu, 1985; Timson and Dudenhoeffer, 1985), the TNF reduction re- ported by Sugie and Verity (1985) could be the consequence of hypotrophy in their animals rather than a direct effect of hypothyrodism, whereas acute antenatal treatment of the chickens does not induce hypotrophy or DNA lowering. In adult rats, surgical thyroidectomy does not modify the TNF but lowers the percentage of fast fibers (lanuzzo et al, 1980; Nwoye and Mommaerts, 1981). In fact, thyroid hormones affect the synthesis of the muscle myosin isoforms during development (Butler-Browne et al, 1984), regeneration (d'Albis et al, 1987), and at the adult stage (Izumo et al, 1986). The myogenesis modifications induced during the embryonic and the perinatal period in our chickens are due to other mechanisms.

Our results show that various treatments able to interact with the thyroid stade of the chicken in ovo decrease T3 plasma level at 3 days, increase the total number of muscle fibers in the plantaris muscle at 3 and 35 days and change in different manners the ontogeny of the various muscle fiber populations. A study of the perinatal variations of thyroid hormone levels and the development of motor innervation of the plantaris muscle in control and treated animals could contribute towards an explanation of our results.

\section{REFERENCES}

Adams AE, Bull AL (1949) The effects of antithyroid drugs on chick embryos. Anat Rec 104, $421-443$

d'Albis A, Weinman J, Mira JC, Couteaux R (1987) Rôle régulateur des hormones thyroïdiennes dans la myogenèse. Analyse des isoformes de la myosine dans la régénération musculaire. CR Acad Sci (Paris) 305, 697-702

Ashmore CR, Vigneron P, Marger L, Doerr L (1978) Simultaneous cytochemical demonstration of muscle fiber types and acetylcholi- 
nesterase in muscle fibers of dystrophic chickens. Exp Neurol 60, 68-82

Bacou F, Jallageas $M$, Nougues J, Vigneron P (1980) Influence of experimental hypothyroidism on chick myogenesis. Reprod Nutr Dev $20,217-224$

Bobek S, Jastrzebski M, Pietras M (1977) Agerelated changes in oxygen consumption and plasma thyroid hormone concentration in the young chicken. Gen Comp Endocrinol 31, 169-174

Butler-Browne GS, Herlicoviez D, Whalen R (1984) Effects of hypothyroidism on myosin isozyme transitions in developing rat muscle. FEBS Lett 166, 71-75

Dainat J, Rebière A (1978) Correction of the biochemical effects of neonatal hypothyroidism by daily low doses of thyroxine. Comparative effects of hyperthyroidism and these corrections. Acta Neurol Scand 58, 167-177

Darras VM, Huybrechts LM, Berghman L, Kühn ER, Decuypere E (1990) Ontogeny of the effect of purified chicken growth hormone on the liver 5' monodeiodination activity in the chicken: reversal of the activity after hatching. Gen Comp Endocrinol 107, 212-220

Decuypere E, Scanes CG (1983) Variation in the release of thyroxine, triiodothyronine and growth hormone in response to thyrotrophin releasing hormone during development of the domestic fowl. Acta Endocrinol 102, 220-223

Geffner DL, Azukizawa M, Herschman J (1975) Propylthiouracyl blocks extrathyroidal conversion of thyroxine to triiodothyronine and augments thyrotrophin secretion in man. J Clin Invest 55, 224-231

Goussopoulos J, Bacou F, Nougues J, Vigneron $P$ (1974) Effet du méthimazole injecté au cours de la vie embryonnaire sur le développement du poulet. XV World Poultry Congr New Orleans 509-510

Grussendorf M, Hüfner M (1977) Induction of the thyroxine (T4) to triiodothyronine (T3) converting enzyme in rat liver by thyroid hormones and analogs. Clin Chim Acta 80, 6166

Guth L, Samaha FJ (1969) Qualitative differences between actomyosin ATPase of slow and fast mammalian muscle. Exp Neurol 25, 138152

Harris ARC, Vagenakis AG, Braverman LE (1979) Sex related difference in outer ring monodeiodination of thyroxine and $3,3^{\prime}, 5^{\prime}-$ triiodothyronine by rat liver homogenates. Endocrinology 104, 645-652

Harvey $S$ (1990) Thyrotrophin-releasing hormone: a growth hormone-releasing factor. J Endocrinol 125, 345-358

Huybrechts LM, Decuypere E, Scanes CG, Callewaert $P$, Peys E, Kühn ER (1985) Human pancreatic growth hormone releasing factor stimulates growth hormone secretion in perinatal dwart and control chickens. Horm Metab Res 17, 690-692

Hylka WW, Tonetta SA, Thommes RC (1986) Plasma iodothyronines in the domestic fowl, newly hatched to early adult stages, with special reference to reverse trilodothyronine (rT3). Comp Biochem Physiol 84, 275-277

lanuzzo D, Patel P, Chen V, O'Brien P, Williams $C$ (1980) A possible thyroidal trophic influence on fast and slow skeletal muscle. In: Plasticity of muscle (Pette D, ed) Walter de Gruyter, Berlin, 593-605

themelandu EC (1985) Fibre number and sizes of mouse soleus muscle in early postnatal protein malnutrition. Acta Anat 121, 89-93

Izumo S, Nadal-Ginard B, Mahdavi V (1986) All members of the MHC multigene family respond to thyroid hormone in a highly tissuespecific manner. Science 231, 597-600

Jennings AS, Crutchfield FL, Dratman MB (1984) Effect of hypothyroidism and hyperthyroidism on triiodothyronine production in perfused rat liver. Endocrinology 114, 992997

Kalliekaran R, Hall BK (1974) A developmental study of the levels of progesterone, corticosterone, cortisol and cortisone circulating in plasma of chick embryos. Gen Comp Endocrinol 24, 364-372

Kaplan MM, Utiger RD (1978) lodothyronine metabolism in liver and kidney homogenates from hyperthyroid and hypothyroid rats. Endocrinology 103, 156-161

Klandorf H, Sharp PJ, Duncan IJH (1978) Variations in levels of plasma thyroxine and triiodothyronine in juvenile female chickens during 24 and $16 \mathrm{~h}$ lighting cycles. Gen Comp Endocrinol 36, 238-243

Kühn ER, Decuypere E, Colen LM, Michels H (1982) Post-hatch growth and development of a circadian rhythm for thyroid hormones in 
chicks incubated at different temperatures. Poult Sci 61, 540-549

Kühn ER, Verheyen G, Decuypere E, Huybrechts L, labal A (1986) Growth hormone and thyrotropin releasing hormone stimulate the peripheral conversion of thyroxine into triiodothyronine and the liver 5'monodeiodinase activity in the adult chicken. IRCS J Med Sci 14, 479

Leonard JL, Rosenberg IN (1978) Thyroxine 5'deiodinase activity of rat kidney: observations on activation by thiols and inhibition by propylthiouracile. Endocrinology 103, 21372144

Nemeth $?$, Norris BJ, Solanki L, Kelly AM (1989) Metabolic specialization in fast and slow muscle fibers of the developing rat. J Nourosci 9, 2336-2343

Newcomer WS (1974) Diurnal ryhthms of thyroid function in chicks. Gen Comp Endocrinol 24, 65-73

Nwoye L, Mommaerts WFHM (1981) The effects of thyroid status on some properties of rat fast-twitch muscle. J Muscle Res Cell Motil 2, 307-320

Oppenheimer JH, Schwartz HL, Surks MI (1972) Propylthiouracile inhibits the conversion of L-thyroxine to L-triiodothyronine. An explanation of the antithyroxine effect of propylthiouracile and evidence supporting the concept that triiodothyronine is the active thyroid hormone. J Clin Invest 51, 2493-2497

Ooka H (1979) Changes in extrathyroidal conversion of thyroxine (T4) to $3,3^{\prime}, 5^{\prime}$ triiodothyronine (T3) in vitro during development and aging of the rat. Mech Ageing Dev $10,151-156$
Peter JB, Barnard RJ, Edgerton VR, Gillespie CA, Stempeike KE (1972) Metabolic profiles of three fiber types of skeletal muscle in guinea pigs and rabbits. Biochemistry 11, 26272633

Ross JJ, Duxson MJ, Harris AJ (1987) Neural determination of muscle fibre numbers in embryonic rat lumbrical muscle. Development $100,395-409$

Scanes CG, Hart LE, Decuypere E, Kühn ER (1987) Endocrinology of the avian embryo: an overview. J Exp Zool 1, 253-264

Silva JE, Matthews P (1984) Thyroid hormone metabolism and the source of plasma triiodothyronine in 2-week old rats: effects of thyroid status. Endocrinology 114, 2394-2405

Schmidt-Achert KM, Askanas V, Engel WK (1984) Thyrotropin-releasing hormone enhances choline acetyltransferase and creatine kinase in cultured spinal ventral horn neurons. J Neurochem 43, 586-589

Sugie H, Verity MA (1985) Postnatal histochemical fiber type differentiation in normal and hypothyroid rat soleus muscle. Muscle Nerve 8 , 654-660

Timson BF, Dudenhoeffer GA (1985) The effect of severe dietary protein restriction on skeletal muscle fiber number, area and composition in weanling rats. J Anim Sci 61, 416-422

Van Doorn J, Roelfsema J, Van der Heide D (1982) Contribution from local conversion of thyroxine to $3^{\prime}, 5^{\prime}, 3^{\prime}$-triiodothyronine to intracellular 3,5,3'-triiodothyronine in several organs of hypothyroid rats at isotope equilibrium. Acta Endocrinol 101, 386-396 